\section{Heat Effects on Nutrient Release from Soils Under Ponderosa Pine}

\section{E. M. WHITE, W. W. THOMPSON, AND F. R. GARTNER}

Highlight: Litter and mor of ponderosa pine-forest soils released more watersoluble $K$ and $P$ following heating to $200 C$ than at higher or lower temperatures. The upper $A 1$ horizon released the most water-soluble $P$ and $K$ following, respectively, $200 \mathrm{C}$ and $500 \mathrm{C}$ heat treatments. Total nitrogen decreased in the samples heated in excess of $200 \mathrm{C}$. Prescribed burning to control noncommercial pine on rangeland apparently would have little detrimental effect on $K$ and $P$ availability and cause $a$ slight reduction in total nitrogen if heating is kept below 200 or $300 \mathrm{C}$.

Wells (1971, p. 90) suggested a need to "... develop methods to predict the results of a burning treatment." Prescribed burning affects the soil by destroying, charring, or heating the surface litter, the underlying partially decomposed mor or 0 -horizon, and the upper mineral soil layer. The effect of heat on nutrient release from soils underlying ponderosa pine (Pinus ponderosa Laws.) was studied in the laboratory. Soils were collected from the forest-grassland ecotone in the foothills of the Black Hills in South Dakota.

\section{Literature Review}

Effects of prescribed burning on soil physical and chemical properties and on fertility were summarized by Ralston and Hatchell (1971) and by Wells (1971). In general, the combustible organic surface layer is affected most and may be partially or entirely destroyed. High temperatures may occur in mineral soil surfaces if the fuel supply is large and burned to "white ash." However, temperature decreases rapidly with depth in the soil and with time following the fire.

Philpot (1970) studied the pyrolysis of pine needles and reported the maximum volatization was between 175 to $350 \mathrm{C}$ with endothermic and exothermic reactions occurring, respectively, at 210 , 350 , and $400 \mathrm{C}$ and at 300 and $475 \mathrm{C}$. At $400 \mathrm{C}, 35 \%$ of the organic compounds remained in the ash. Hosking (1938)

The authors are professor in the Plant Science Department and assistant and associate professors in the Animal Science Department (Range Management) South Dakota State University, Brookings.

The paper was approved for publication by the director of the Agricultural Experiment Station, South Dakota State University, Brookings, as Journal Series No. 1079.

Manuscript received April 3, 1972. reported soil organic matter lost some weight below $100 \mathrm{C}$ and then underwent nondestructive and destructive distillation, respectively, from 100 to $200 \mathrm{C}$ and from 200 to $300 \mathrm{C}$. In the 200 to $300 \mathrm{C}$ range, loss of organic matter increased to about $85 \%$ of the total. Ignition of the carbonaceous residue occurred above 300 C. Thus, the maximum change in organic matter would probably occur below 300 C. Additional changes could occur from reactions of the inorganic elements released from the organic matter and from the soil, expecially at higher temperatures.

Many inorganic soil materials, particularly the partially weathered micaceous minerals and clays, dehydrate at relatively low temperatures. Dehydration, in addition to an inversion of low temperature crystalline forms to higher temperature forms, could increase or decrease the solubility of $\mathrm{P}$ and $\mathrm{K}$ from the mineral. At higher temperatures, chemical changes of the mineral surfaces could be caused by alkaline or alkaline-earth compounds, either from the heated minerals or from organic matter combustion. Such changes might increase or decrease the solubility of $\mathbf{P}$ or $\mathrm{K}$ depending upon the chemical compounds formed when the material cools. Rapid heating and cooling may break a mineral apart as it expands and contracts. The fresh unweathered surfaces could release $\mathrm{P}$ and $\mathrm{K}$ more rapidly than weathered surfaces.

\section{Materials and Methods}

Duplicate samples of litter and A1 horizon were collected at 6 locations at the east (locations 1 through 4 ) and north (locations 5 and 6) foothills of the Black Hills where the ponderosa pine encroaches onto the plains grassland. Mor samples also were collected, except at location 5 where none was present. Litter consists primarily of partially decomposed, but identifiable, pine needles. Mor consists of almost completely decomposed organic debris beneath the litter. The Al horizon material consisted of the upper $4 \mathrm{~cm}$ of the mineral soil. Soils were derived from Dakota sandstone (locations 1, 2, and 3), from acid to weakly calcareous Graneros shale (location 4), from very calcareous Spearfish shale (location 5), and probably from Dakota sandstone (location 6).

Samples reported for the $25 \mathrm{C}$ heat treatment were at laboratory temperatures; the 50, 100, and $200 \mathrm{C}$ samples were heated in a laboratory drying oven; and the 300,400 , and $500 \mathrm{C}$ samples were heated in a muffle furnace. These temperatures span the range found in a controlled burn of dense second-growth ponderosa pine conducted near one of the sample sites. Very thin, rectangular plates were striped with several crayons that melted at different temperatures. The plates were wrapped with aluminum foil and inserted into the litter, mor, and the upper $6 \mathrm{~cm}$ of the mineral soil.

For water-soluble $\mathrm{P}$ and $\mathrm{K}$ determinations, 3 to 5 gram samples were heated for 1 hour at the designated temperature, cooled, transferred to $125 \mathrm{ml}$ Erlenmeyer flasks, extracted with $100 \mathrm{ml}$ of $\mathrm{H}_{2} \mathrm{O}$ for 10 minutes on an oscillating shaker, and the supernatant was filtered through Whatman No. 42 filter paper. K was detcrmined with a flame photometer and $P$ with the chloromoybdic acid-colorimetric method (Jackson, 1958). Total water-soluble $P$ (includes organic-bound $\mathrm{P})$ in the leachate and total $\mathrm{P}$ and $\mathrm{K}$ of the samples were determined following a perchloric acid digestion. Separate samples were used for the total $\mathrm{N}$ determination by the Kjeldahl procedure.

\section{Results and Discussion}

The nitrogen content of the litter, mor, and Al horizon samples (Fig. 1) did not decrease until combustion was initiated at temperatures greater than $200 \mathrm{C}$. About one-half to two-thirds of the nitrogen was lost when samples were heated to $400 \mathrm{C}$, which corresponds to organic matter or nitrogen losses reported by Philpot (1970) and DeBell and Ralston (1970); and only a trace remained at 500 C (determined, but not reported in Fig. 1).

Nitrogen loss depended on the degree of combustion of the sample. At $200 \mathrm{C}$, the samples were darkened, but charring 
was slight. The quantity of white ash in the charred material increased from 300 to $500 \mathrm{C}$. At $300 \mathrm{C}$, some plant fragments burned more completely than others; therefore, grayish-ash fibers were mixed with easily identified charred plant fragments. Presumably, combustion was more complete where the grayish ash was formed and the temperature was locally greater than the furnace temperature. Because of the probable sample and furnace temperature differences, the 300 $C$ heat treatment was not used on samples for water-soluble $\mathrm{K}$ and $\mathrm{P}$ extraction.

Heat effects on the release of total and
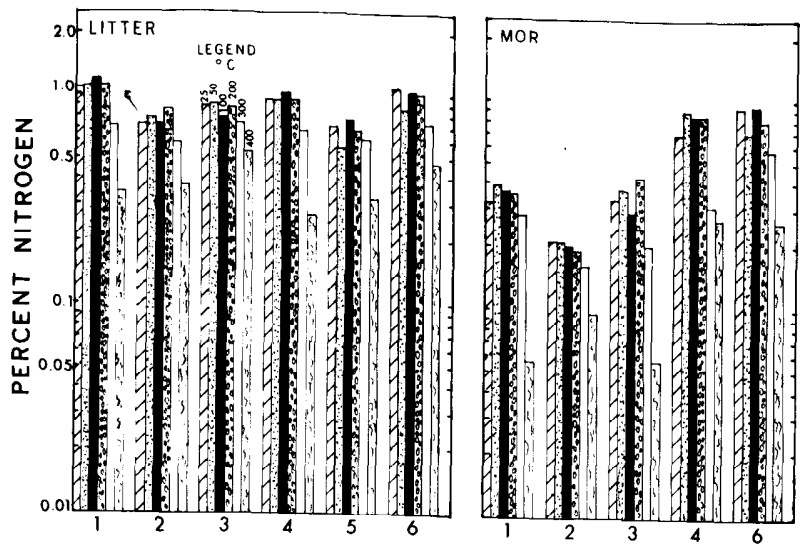

LOCATION AND TEMPERATURE
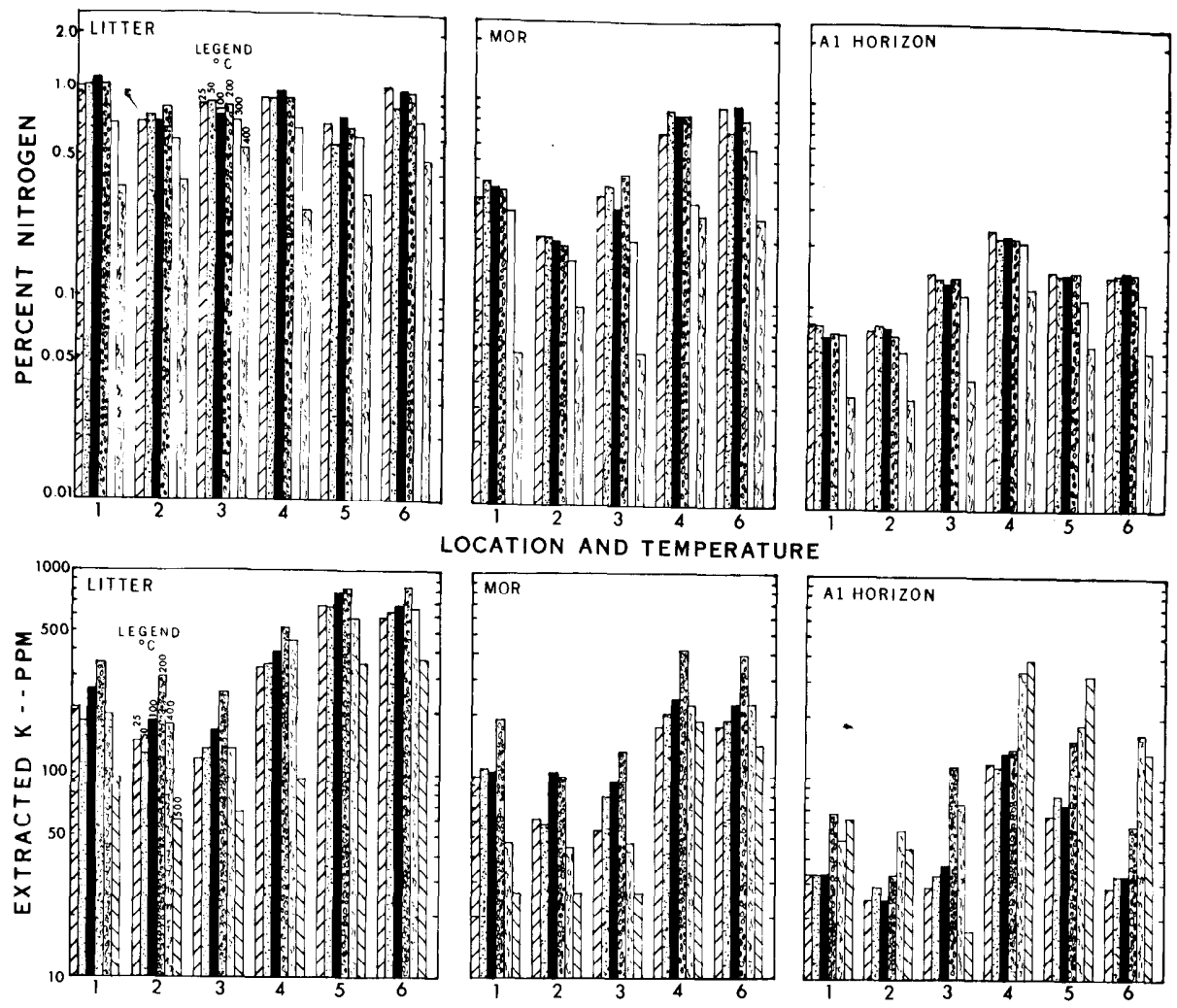

LOCATION AND TEMPERATURE

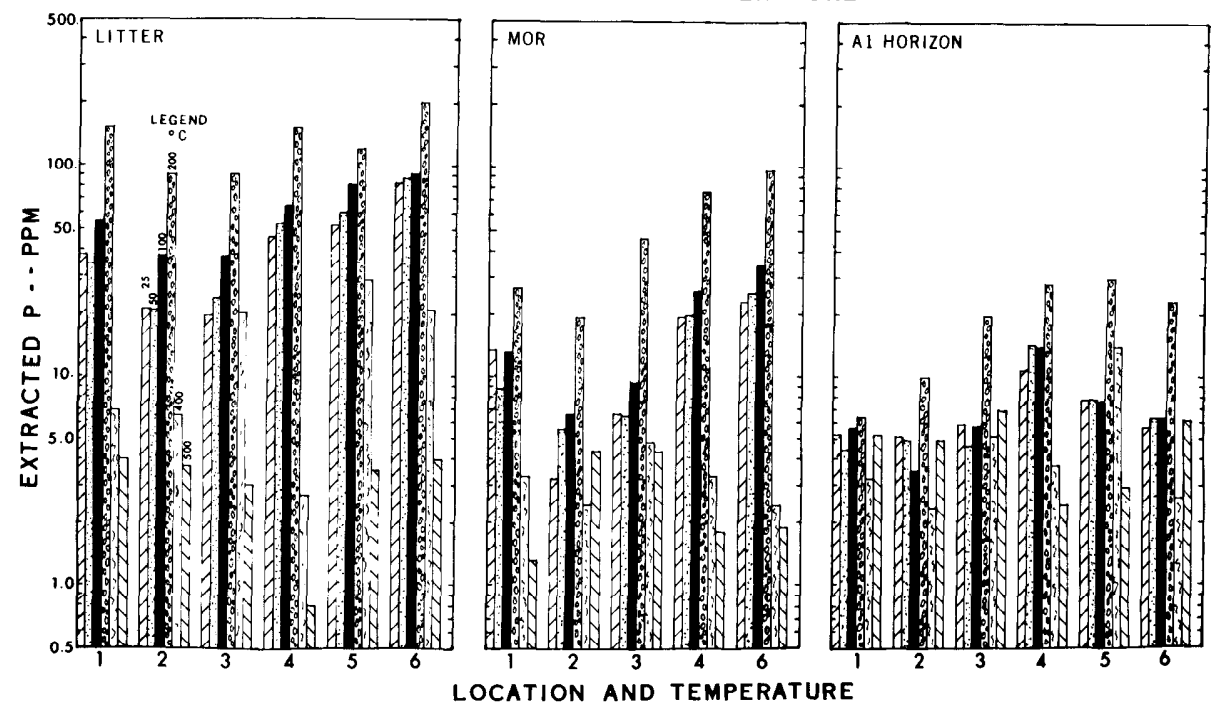

Fig. 1. Effects of heat treatments on the total $N$ and water-soluble $P$ and $K$ contents of litter, mor, and upper $A 1$ horizon of Ponderosa-pine-forest soils. water-soluble $K$ from the samples are more complex than those for $\mathrm{N}$. Total $\mathrm{K}$ contents of some samples heated to 500 $C$ were equal or greater than the unheated samples (Table 1); volatilization of $\mathrm{K}$ (Jackson, 1958, p. 334) may not occur. Lower total $\mathrm{K}$ content of the unheated samples (compared to heated samples) was probably caused by incomplete digestion of the unground unheated samples in the perchloric acid. This digestion is recommended for finely ground samples. Thermal fracturing of K-rich minerals could substitute for grinding so that extraction would be greater from heated than from unheated samples. Quartz in the sandstone-derived soils at location 1 contains little $\mathrm{K}$, so thermal fracturing would not increase $\mathrm{K}$ release (Table 1). Shale-derived soils at locations 4 and 5 released morc $\mathrm{K}$ following $500 \mathrm{C}$ heating than the unheated samples. Presumably, the $\mathrm{K}$ was released by thermal fracturing of micaceous minerals (Raman and Jackson, 1965). A loss of $\mathrm{K}$ by volatilization may be compensated for by additional release of $\mathrm{K}$ from minerals following heating. In any event, relative amounts of the water-soluble $\mathrm{K}$ extracted from litter, mor, or Al horizon after heating to different temperatures were similar for the different locations.

The water-soluble $K$ released was largest from litter and mor heated at 200 C. $\mathrm{K}$ may have been released from the partial decomposition and rearrangement of chemical bonds of the organic matter. At temperatures greater than $200 \mathrm{C}, \mathrm{K}$ may have been volatilized or combined into insoluble compounds with silicate and other inorganic anions released from the organic matter. Regardless of the cause, heating from 200 to $500 \mathrm{C}$ decreased the water-soluble $K$ content of the litter and mor. Heating to temperatures greater than $200 \mathrm{C}$ increased the water-soluble $\mathrm{K}$ extracted from the A1 horizon samples at locations 4,5 , and 6 and not from the other 3 locations. Thus, 
Table 2. The water-extracted $\mathrm{P}(\%)$ in the $\mathrm{PO}_{4}-\mathrm{P}$ form at each heat treatment for the profile samples. Values are averages of all analyses from the seven locations.

\begin{tabular}{lrrrrrr}
\hline \hline & \multicolumn{7}{c}{ Temperature of heating 1} \\
\cline { 2 - 7 } Sample & $25 \mathrm{C}$ & $50 \mathrm{C}$ & $100 \mathrm{C}$ & $200 \mathrm{C}$ & $400 \mathrm{C}$ & $500 \mathrm{C}$ \\
\hline Litter & 71.85 & 78.30 & 74.85 & 37.23 & 91.31 & 53.91 \\
Mor & 96.30 & 113.72 & 103.08 & 39.70 & 80.78 & 67.68 \\
A1 horizon & 26.20 & 33.93 & 36.93 & 101.87 & 92.18 & 94.60 \\
\hline
\end{tabular}

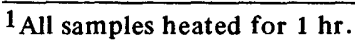

release of water-soluble $\mathrm{K}$ by thermal fracturing in $\mathrm{A} 1$ horizon samples from locations 4,5 , and 6 apparently is greater than the loss from volatilization or fixation in insoluble forms.

Phosphorus is less apt to volatilize than $\mathrm{K}$ at high temperatures. Differences in total $\mathrm{P}$ contents of $25 \mathrm{C}$ samples and those heated to $500 \mathrm{C}$ (Table 1) can be attributed to variations in the unground samples. Like $\mathrm{K}$, the amount of watersoluble $\mathbf{P}$ was largest in litter, intermediate in mor, and least in Al horizon samples. Water-extracted $\mathbf{P}$ amounts found were similar for litter samples collected at the different locations (Fig. 1). However, the amount in the A1 horizon, and to a lesser extent from the mor, seemed related to the total quantity in the $\mathrm{A} 1$ horizon (Table 1) at that location.

The extracted water-soluble $P$ content was largest from litter, mor, and A1 horizon samples heated to $200 \mathrm{C}$. For each kind of sample collected at locations 4,5 , and 6 , the water-soluble $P$ content decreased at higher temperatures. In contrast, A1 horizon samples from locations 1,2 , and 3 released similar amounts of water-soluble $\mathrm{P}$ following heating either above or below 200 C. Apparently, soilmineral differences at the 6 locations affected the release of water-soluble $P$ from the samples that were heated to different temperatures.

The average percent of $\mathrm{P}$ in the water extracts, that is in the $\mathrm{PO}_{4}$-ion form (rather than complexed with organic or inorganic soluble ions), is least for the litter and mor samples heated to $200 \mathrm{C}$ than to higher or lower temperatures (Table 2). Presumably by heating to 200 $\mathrm{C}$, nondestructive volatilization (Hosking, 1938) and structural changes preceding the $210 \mathrm{C}$ endothermic reaction (Philpot, 1970) reduce the $\mathrm{PO}_{4}$-ion solubility. In contrast, the Al horizon water-soluble $\mathrm{P}$ had the smallest amount of uncomplexed $P$ in the samples heated to less than $200 \mathrm{C}$ and the greatest in samples heated to 200 $\mathrm{C}$ or higher. Dehydration may have destroyed the water-soluble complexingagent bonds to free the $\mathrm{PO}_{4}$-ions.

The results of this laboratory study probably can be used to predict the effect controlled burning has on nutrient release. Samples that were heated, either in the laboratory or in the controlled burn area, had similar physical characteristics (described previously for the laboratory study) if the temperatures were comparable. In the controlled burn area, the litter and mor were, respectively, 3 and 1 $\mathrm{cm}$ thick. Maximum temperatures were $343 \mathrm{C}$ a few centimeters above the litter, $245 \mathrm{C}$ in the litter, and $177 \mathrm{C}$ in the mor. Mineral-soil maximum temperatures decreased from 165 to $65 \mathrm{C}$ with depth. Thus, the detrimental effects of this controlled burn on nutrient release apparently would be negligible, except possibly in the litter if the temperature in the field and the laboratory can be compared directly.

Field-measured temperatures are an average temperature of a volume of soil or air, although the temperature of a plant fragment in the volume may be much higher when it burns. The temperatures of the laboratory heat treatments at $200 \mathrm{C}$ or less are not subject to this error because the samples did not burn. At the $300 \mathrm{C}$ temperature in the laboratory, some plant fragments burned more completely than others. This burning releases heat which increases the fragment temperature to something greater than the furnace temperature. The fragments in laboratory samples heated to 400 and $500 \mathrm{C}$ had a more uniform color and fabric and presumably were heated to the same temperature. Although direct evidence is lacking, the physical appearance of the ash, partially burned plant in assessing the effects of fire on the soil.

Prescribed burning as simulated in the laboratory may increase the quantity of water-soluble $P$ and $K$ in litter, mor, and upper A1 horizon of the soil if the temperature does not exceed $200 \mathrm{C}$. The total $\mathrm{N}$ content does not change until temperature exceeds $200 \mathrm{C}$. At higher temperatures, the water-soluble $\mathrm{P}$ and the total $\mathrm{N}$ content generally decreases for the litter, mor, and $\mathrm{A} 1$ horizon. The water-soluble $\mathrm{K}$ content in litter and mor decreased, but for most A1 horizons it fragments, and soil surface may be useful increased if heated to temperature greater than $200 \mathrm{C}$.

The appearance of the burned residue probably can be used as a guide to the effect of fire on total $\mathrm{N}$ content and the water-soluble $\mathbf{P}$ and $\mathrm{K}$. Temperatures of $200 \mathrm{C}$ darken and slightly char the organic fragments in the samples. From 200 to $400 \mathrm{C}$, the grayish-ash skeletal remains of plant fibers become more numerous, and between 400 and $500 \mathrm{C}$ the combustible material is essentially destroyed, leaving a grayish ash residue for the organic-rich litter and mor and a reddish or grayish residue for the upper mineral A1 horizon.

\section{Literature Cited}

DeBell, D. S., and C. W. Ralston. 1970. Release of nitrogen by burning light forest fuels. Soil Sci. Soc. Amer. Proc. 34:936-938.

Hosking, J. S. 1938. The ignition at low tempcratures of the organic matter in soils. J. Agr. Sci. 28:393-400.

Jackson, M. L. 1958. Soil-chemical analysis. Prentice-Hall, Inc. Englewood Cliffs, New Jersey.

Philpot, C. W. 1970. Influence of mineral content on the pyrolysis of plant material. Forest Sci. 16:461-471.

Ralston, C. W., and G. E. Hatchell. 1971. Effects of prescribed burning on physical properties of soil. Prescribed Burning Symposium Proc. 1971:68-84. Southeastern Forest Exp. Sta., Asheville, North Carolina.

Raman, K. V., and M. L. Jackson. 1965. Mica surface morphology changes during weathering. Soil Sci. Soc. Amer. Proc. 29:29-32.

Wells, C. G. 1971. Effects of prescribed burning on soil-chemical properties and nutrient availability. Prescribed Burning Symposium Proc. 1971:86-97. Southeastern Forest Exp. Sta., Asheville, North Carolina.

\footnotetext{
Statement of Ownership, Management and Circulation Act of August 12, 1970, Sec. 3685. Title 39, United States Code) 1. Title of Publication: JOURNAL OF RANGE MANAGEMENT 2. Date of Filing: September 20,1972

3. Frequency of Issue: Bimonthly

4. Location of Office of Publication: 2120 S. Birch St., Denver, Colo. 80222

5. Location of General Business Office: Same

6. Names and Addresses of-

Publisher: Society for Range Management, 2120 S. Birch St., Denver, Colo. 80222

Editor: Elbert H. Reid, 624 S. Shields St., Fort Collins, Colo. 80521

Managing Editor: Francis T. Colbert, $2120 \mathrm{~S}$. Birch St. Denver, Colo. 80222

7. Owner: Society for Range Management, $2120 \mathrm{~S}$. Birch St. Denver, Colo. 80222. A nonprofit corporation; no capital stock authorized.

8. Known Bondholders, Mortgages, etc.: None

9. (Not applicable)

10. For Completion by Nonprofit Organizations Authorized to Mail at Special Rates: The purpose, function, and nonprofit status of this organization and the exempt status for Federal income tax purposes have changed during the preceding 12 months (explanatory statement attached).

11. Extent and Noture of Circulation:

A. Total copies printed
B. Paid circulation

1. Dealers, counter sales

2. Mail subscriptions

C. Total paid circulation

D. Free distribution

1. Samples, complimentary

2. To news agents, not sold

E. Total distribution

$\mathrm{F}$. Office use, unaccounted

G. Total

Ave. for Actual for issue 12 months nearest filing dat 2 months nearest filing
5,266
5,200

certify that the statements ma,266 5,200 complete_francis $T$. Colbert, Managing Editor.
} 